\title{
Desistência em Caso de Comparticipação
}

\author{
ABRÃO AMISY NETO'
}

\section{Introdução}

O objeto da investigação é o instituto da desistência em caso de comparticipação, ou seja, a relevância e as consequências do abandono ou do arrependimento do propósito criminoso por parte de um dos agentes que concorrem para o crime.

A importância do estudo relaciona-se basicamente com a regulamentação prevista no Código Penal ${ }^{2}$ que, longe de ser uma crítica, apresenta respostas singulares quando confrontado com outros ordenamentos jurídicos que tratam da matéria com distintas soluções ou, como é o caso do Brasil, que desconhecem por completo na lei penal eventuais particularidades decorrentes da específica situação.

Para atingir o objetivo proposto, buscamos estabelecer inicialmente as bases jurídicas que sustentam a desistência e a relação com a figura do "crime tentado" que, regra geral, apresenta-se como principal referência, medida e seu limite.

A natureza jurídica da desistência, o seu fundamento, os requisitos e as hipóteses que autorizam a respectiva incidência ou exclusão serão tratados de maneira a apresentar as diversas opiniões que, apesar de muitas vezes antagónicas, contribuem para parciais conclusões que serão relevantes para os subtemas posteriores.

Em continuidade, compreendemos imprescindível a apresentação de conceitos relativos à comparticipação, nomeadamente com o fim de distinguir os diversos papéis que os indivíduos podem desempenhar no ilícito penal e as consequências para cada uma das hipóteses, a depender de serem protagonistas (figuras centrais) ou coadjuvantes (figuras acessórias) na realização do evento criminoso.

\footnotetext{
1 Procurador de Justiça do Ministério Público do Estado de Goiás. Mestre em Ciências da Educação (Pontifícia Universidade Católica de Goiás). Mestrando em Ciências Jurídicas (Universidade Autónoma de Lisboa).

2 Neste trabalho, a referência "Código Penal" indica o Código Penal português ora vigente.
} 
Ofertadas as observações a respeito da desistência e da comparticipação, será possível analisar a regulamentação portuguesa da "desistência em caso de comparticipação", tema principal do trabalho.

No percurso investigativo, apresentaremos os aspectos jurídicos que acreditamos mais importantes, as divergências existentes entre os doutrinadores e, sempre que possível, as referências jurisprudenciais, a incluir, por acreditarmos importante, a posição de penalistas brasileiros e o tratamento dispensado pelo Código Penal brasileiro, cuja regulamentação é bastante lacónica quando comparada à lei portuguesa.

Ao final, serão expostas as nossas conclusões sobre as questões mais importantes, inclusive aquelas que acreditamos passíveis de críticas

\section{Crime Tentado e Desistência}

É de MANTOVANI a afirmação de que "o delito, como ato humano, nasce, vive e morre"3.

O caminho do crime, do nascimento até a sua morte, utilizando-se da metáfora acima retratada, é composto de diversas fases denominadas doutrinariamente em seu conjunto como iter criminis e que vem retratar as etapas que se iniciam com a ideia criminosa e findam com a consumação, na qual os elementos do tipo penal encontram-se objetiva e subjetivamente preenchidos.

Tais fases são as seguintes: a) cogitação (cogitatio); b) preparação (conatus remotus); c) execução (conatus proximus); e, por último, d) consumação.

Em síntese, o iter criminis possui uma fase interna (cogitação) e três fases externas (preparação, execução e consumação) ${ }^{4}$.

Quanto à fase interna, é indiscutível que a intervenção penal não pode ser ampla a ponto de punir valores morais ou ideias censuráveis do indivíduo, pois de tais situações não há como resultar lesão ou perigo de lesão ao bem jurídico eventualmente tutelado, razão pela qual a cogitação (primeira fase do iter criminis) é impunível: cogitationis poenam nemo patitur 5 .

Em relação aos atos preparatórios, a regra é também de afastamento da punição, até mesmo por dificilmente encontrarem-se descritos no tipo penal e também por não possuírem aptidão, por si, para colocar em risco o bem jurídico.

\footnotetext{
3 Mantovani apud PRADO, Luiz Regis - Curso de Direito Penal Brasileiro. p. 371.

4 É evidente que em alguns casos não haverá como vislumbrar tais fases de maneira cartesiana, pois a complexidade da ação humana "e recorrência de motivações se não coaduna com a frieza do rigor classificatório" (COSTA, José Francisco de Faria - Formas de Crime. p. 158).

5 "Ninguém pode sofrer pena pelo pensamento".
} 
Contudo, tal regra admite exceções, o que é objeto de expressa previsão no art. $21 .^{\circ}$ do Código Penal: "Os actos preparatórios não são puniveis, salvo disposição em contrário"6.

Pode ocorrer, porém, que a última fase do iter criminis não se verifique, isto é, presentes a cogitação, a preparação e iniciada a execução, não há a reunião de todos os elementos pertinentes ao crime, nomeadamente os relacionados ao tipo objetivo.

Neste contexto, de acordo com o art. 22. $.^{\circ}, \mathrm{n} .^{\circ}$ 1, do Código Penal, existe a tentativa (conatus, "crime imperfeito", "crime inacabado" ou "crime incompleto") que, na definição da lei, ocorre "quando o agente praticar actos de execução de um crime que decidiu cometer, sem que este chegue a consumar-se".

É assim possível constatarmos pela referida redação que a tentativa é possuidora dos seguintes elementos: a) decisão pelo cometimento do facto; b) prática de atos de execução; e, finalmente, c) não consumação do crime.

Na tentativa, portanto, estão presentes dois elementos, um deles subjetivo (intenção de realizar o tipo) e um objetivo (ação de execução do tipo), bem como ausente o terceiro elemento, daí ser denominado por CIRINO DOS SANTOS de "elemento negativo da tentativa", que vem a ser o próprio resultado 7 , o que a caracteriza como tipo incompleto: estrito preenchimento do tipo subjetivo e ausência do tipo objetivo ${ }^{8}$.

Não consumado o delito, poderia ser indagado o porquê da punição, isto é, os fundamentos que recomendam que o crime tentado não seja considerado um irrelevante penal.

Repisamos que, por não existir um "crime tentado" desvinculado da intenção consumativa, é adequado defender a posição de que não há distinção ontológica entre o fundamento da punição do crime tentado e o fundamento da punição do crime consumado, embora o primeiro apresente um menor desvalor do resultado.

Assim, por coerência, não se deve olvidar que o fundamento da punibilidade da tentativa, tal como do crime consumado, demanda a análise a respeito da função do Direito Penal no respectivo ordenamento jurídico: se é a proteção do bem jurídico, o fundamento preponderante é o perigo a ele próprio; se é a reafirmação de vigência da lei penal, o funda-

6 O Código Penal, por exemplo, prevê a punição no art. $262 .^{\circ}$, que trata do delito de "contrafacção de moeda", e no art. $271 .^{\circ}$, que pune actos preparatórios, por esta própria natureza, além de outros tipos penais nos quais tais actos são punidos.

7 SANTOS, Juarez Cirino - Direito Penal: Parte Geral. p. 384.

8 É a tentativa um "tipo dependente", isto é, não existe por si mesma, conforme ensina GALDINO SIQUEIRA: "O exposto mostra ainda que constitui a tentativa uma forma degradada do delito consumado, mas considerada em si mesma formando um crime perfeito, não tem, porém, autonomia pode constituir um crime sui generis, autônomo ou infração contravencional como pretendem alguns autores" (Tratado de Direito Penal. p. 560). Consequentemente, a punição advém de uma "norma de ampliação de conduta" ou "norma de adequação típica de subordinação mediata". 
mento é o abalo da confiança da comunidade na norma jurídica; se ambos, haveria então um fundamento híbrido ou misto a sustentar a punição.

Para maior esclarecimento, merecem ser apresentadas as teorias vinculadas ao tema: a) teoria subjetiva ou voluntarística: a punição advém da intenção criminosa, isto é, no desvalor da ação, o que poderia justificar a pena similar entre o crime tentado e o consumado; b) teoria sintomática: a tentativa revela a periculosidade do agente, razão pela qual seria possível até mesmo a punição dos atos preparatórios (Escola Positivista, nomeadamente); c) teoria objetiva, causalista ou dualista: considera preponderantemente o perigo ao bem jurídico tutelado, a expressar o desvalor do resultado e a merecer, assim, uma pena menor; d) teoria objetivo-subjetiva ou teoria da impressão: postula que a punição pelo crime tentado resulta do facto de a própria execução do delito, ainda que não alcançado o propósito do agente e desde que configure uma relevante intervenção no ordenamento jurídico, ser apta a materializar a dignidade penal do facto e a criar na comunidade a impressão de ofensa ao direito, o que indicaria a necessidade de reprimenda com o fim de restabelecer a confiança na vigência da norma; e) teoria da união: elaborada por ROXIN ${ }^{9}$, busca a aproximação dos fundamentos da punição derivada do perigo próximo ao tipo, o que seria a regra, e da violação perturbadora da norma quando próximo tal perigo, o que seria a exceção, ambas as derivações sustentadas nos fins preventivos da pena ${ }^{10}$.

Das teorias expostas, compreendemos mais compatível com o ordenamento jurídico-penal de Portugal a teoria da impressão, que inclusive se mostra majoritária.

Uma outra questão que merece análise, pois será relevante nas regras relativas à desistência na comparticipação, refere-se à linha divisória entre atos preparatórios e execução do delito, pois justificará a punição ou não a depender do estágio alcançado no iter criminis.

No Brasil, até mesmo pela ausência de maior especificidade normativa a respeito do que se considera início da execução, adota-se de forma preponderante a teoria "objetivo-formal" ou "lógico-formal", de acordo com a qual o início da execução é caracterizado pela definição do núcleo do tipo, ou seja, pela prática de conduta que preencha o seu elemento central.

O Código Penal português, embora também acolha a referida teoria, acrescenta outras hipóteses por ela não abarcadas a respeito do que vem a ser "atos de execução", o que está expresso no art. 22..$^{\circ}$ n..$^{\circ}$ 2: "a) Os que preencherem um elemento constitutivo de um tipo de crime; b) Os que forem idóneos a produzir o resultado típico; ou c) Os que, segundo a

9 ROXIN, Claus - Derecho Penal: Parte General. Tomo 2. p. 436

10 FIGUEIREDO DIAS, franco defensor da "teoria da impressão", critica a teoria propugnada por ROXIN e afirma que os problemas relacionados à tentativa impossível não poderiam ser respondidos sem referência à teoria da impressão (Direito Penal: Parte Geral. p. 692). 
experiência comum e salvo circunstâncias imprevisíveis, forem de natureza a fazer esperar que se lhes sigam actos das espécies indicadas nas alíneas anteriores".

Regra geral, o início da execução do delito culmina em sua consumação, conforme foi possivel apreender das etapas do iter criminis.

Apesar disto, há casos, por certo não raros, que o caminho do crime não alcança a consumação, embora iniciada a execução. Tal situação pode ocorrer pelo advento de alguma circunstância não desejada pelo agente ou, por outro modo, por alguma outra convergente com a sua vontade, seja, por exemplo, pelo intermédio do abandono da execução ou pela prática de condutas que tiveram a finalidade de impedir que o crime se consumasse.

Em conformidade com a última hipótese, estatui o Código Penal, em seu art. $24 .^{\circ}, \mathrm{n} .^{\circ} 1$, sob a denominação "desistência": "A tentativa deixa de ser punível quando o agente voluntariamente desistir de prosseguir na execução do crime, ou impedir a consumação, ou, não obstante a consumação, impedir a verificação do resultado não compreendido no tipo de crime".

É correto estabelecermos os seguintes requisitos iniciais de ordem alternativa que possibilitam a não punição - ou menor punição - do agente pela desistência: a) abandono voluntário da execução"1; b) impedimento da consumação mediante uma contra-conduta, se já esgotados os atos de execução; c) impedimento da produção do resultado não compreendido no tipo mediante uma contra-conduta, se já consumado formalmente o delito.

Quanto à natureza da desistência, não se desconhece relevante posição doutrinária no sentido de que resulta a sua ocorrência em atipicidade, tese acolhida de forma muito mais favorável no Brasil do que em Portugal, nomeadamente pela redação contida no Código Penal brasileiro.

Assim, o seu art. $14{ }^{\circ}$, inciso II, dispõe que se considera tentado o crime quando, iniciada a execução, "não se consuma por circunstâncias alheias à vontade do agente".

Portanto, se o agente abandonou a execução ou impediu a produção do resultado, o delito não teria se consumado por circunstâncias inerentes e não alheias à sua vontade, o que afastaria a tipicidade da tentativa ${ }^{12}$.

11 Somente é possível falar em desistência quando transporta a linha divisória entre atos preparatórios e começo da execução e antes da consumação do delito. Como regra, antes da consumação formal. Em Portugal, como será visto de maneira pormenorizada, existe singular ampliação ao possibilitar os benefícios da desistência mesmo após a consumação formal, desde que antes da consumação material, além de hipótese mais ampla na desistência em caso de comparticipação.

12 Neste sentido, afirma CEZAR ROBERTO BITENCOURT que se trata de "causa de exclusão da adequação típica" em razão do teor do art. $14 .^{\circ}$, inciso II, do Código Penal brasileiro, uma vez que o não atingimento da consumação adveio, afinal, da própria vontade do agente: "Não havendo tentativa, pela falta de um dos seus elementos (não-ocorrência por circunstâncias alheias à vontade do agente), não se pode falar em extinção da punibilidade, mas deve-se falar tão-somente em inadequação típica" (Teoria Geral do Delito. p. 482). 
A atipicidade, para outros autores, também poderia ser sustentada na ausência de dolo, pois se o agente cessa a prática da qual resultaria o resultado inicialmente almejado ou vem a praticar algum ato na direção contrária da realização completa do evento criminoso, restaria ausente o elemento subjetivo indispensável ao crime tentado e aí também residiria a atipicidade advinda da desistência ${ }^{13}$.

Apesar disto, a presença de doutrinadores que compreendem a desistência como causa pessoal de afastamento da punição é bastante expressiva ${ }^{14} \mathrm{e}$, para a defesa da tese, a excluir a redação da norma de extensão da tentativa, pouco favorável a ela, os argumentos apresentados não diferem fundamentalmente daqueles encontrados na doutrina portuguesa ${ }^{15}$, especialmente pela elaboração de um raciocínio de difícil contestação: o que é típico no início de execução, tanto objetivamente quanto subjetivamente, não se transforme em atípico em virtude da desistência: "a tentativa uma vez acontecida não pode ser suprimida retroativamente"16 17 .

No contexto da comparticipação, aliás, é certo que a compreensão da desistência como causa de atipicidade implicaria solução contrária à normatização do instituto no Código Penal português, especialmente pelo facto de que a atipicidade da conduta do autor automaticamente beneficiaria o outro que não pretendia abandonar a execução e que eventualmente buscou, ainda que sem sucesso, a consecução do plano inicial, conclusão oposta ao sistema de responsabilidade apresentado na lei ${ }^{18}$.

Além das categorias "tipicidade" e "punibilidade", há aqueles que afirmam ser a natureza jurídica da desistência causa de exclusão ou de extinção da culpabilidade.

Para ROXIN, a desistência implicaria ausência do injusto penal e, por conseguinte, do que prevenir, a afastar a culpabilidade, o que é compativel com o seu pensamento de a culpabilidade vincular-se à finalidade da pena ${ }^{19}$.

Porém, tal elaboração é objeto de crítica por autores como ZAFFARONI, especificamente sob o argumento de que esta teoria padece do mesmo problema da teoria da atipici-

13 É a posição de Ângelo Raffaele Latagliata em sua obra La Desitenza Voluntaria (apud ZAFFARONI, Eugênio Raúl - Da Tentativa: Doutrina e Jurisprudência. p. 89).

14 Para GALDINO SIQUEIRA trata-se de isenção de pena, "por isso que deixa intactos os elementos constitutivos da tentativa punível, afastando apenas a sanção penal, por considerações de ordem utilitária" (Op. Cit. p. 588).

15 É certo que a redação da lei penal a respeito da desistência em Portugal indica a pouca possibilidade de acolhimento de tese distinta, uma vez que o art. $24 .^{\circ}$, n. $^{\circ} 1$, dispõe que, na desistência, a "tentativa deixa de ser punivel (...)".

16 HUNGRIA, Nelson; FRAGOSO, Heleno Cláudio - Comentários ao Código Penal. p. 93.

17 Como afirma LISZT, “o facto não pode mais ser alterado, supprimido ou 'annulado retroativamente'. Pode porém a lei, por considerações de política criminal, construir uma ponte de ouro para a reirada do agente que já se tornará passível de pena"' (LISZT, Franz von - Tratado de Direito Penal Alemão. p. 342).

18 Para FIGUEIREDO DIAS, a natureza jurídica da desistência é de pressuposto negativo da punibilidade em decorrência da falta de dignidade punitiva do facto global (Op. Cit. p. 862).

19 Op. Cit. p. 602 
dade, uma vez que não seria possível compreender que uma propósito posterior seja apto a afastar a reprovabilidade da conduta anterior já praticada ${ }^{20}$.

Afastada a natureza jurídica da desistência das categorias "tipicidade" e "culpabilidade", passa-se a analisar os fundamentos que recomendam a não punição ("punibilidade").

Como ideia geral, o seu fundamento tem nítida inspiração político-criminal consistente, por um lado, no afastamento do perigo ao bem jurídico tutelado e, por outro, na extinção da "impressão ameaçadora que a tentativa apresenta" ${ }^{21}$, de maneira tal que a não punição, apesar da tipicidade da tentativa, acaba por representar, mas não somente, um prémio pelo novo caminho que o agente optou por percorrer.

A teoria do direito premial (teoria da graça ou teoria do perdão) como fundamento da desistência por certo não é a única, sendo possível encontrar na doutrina outras teorias: a) teoria dos fins da pena: a desistência indicaria a desnecessidade da pena por ter o agente "regressado" ao direito; b) teoria político-criminal: a desistência estimularia o agente a não prosseguir na consumação a partir da concessão de benefícios mais amplos do que a do crime tentado, o que foi denominado por LISZT, a partir de FEUERBACH, como "ponte de ouro".

A respeito da desnecessidade da pena em virtude do "regresso ao direito", cuja formulação é conferida preponderantemente ao alemão ROXIN, a crítica relaciona-se com o facto de o privilégio da desistência ser concedido ainda que o abandono da execução ou o impedimento da consumação não sejam decorrentes de uma motivação ética por parte do agente, bastando a voluntariedade, o que indicaria, a depender de uma motivação menos nobre, ao menos no nível teórico, a necessidade da prevenção especial.

Quanto à teoria incorporada por LISZT, que encontra boa acolhida na doutrina penal brasileira, a objeção é a seguinte: para alguém ser estimulado a algo é necessário que possua ciência da existência dos critérios de merecimento para alcançar o benefício, o que não é comum ao cidadão não familiarizado com as leis penais ${ }^{22} 23$.

De qualquer forma, concordamos com FIGUEIREDO DIAS quando afirma ser impossível a adoção de uma teoria única para fundamentar a impunidade pela desistência, até mesmo em razão de, no limite, as teorias interrelacionarem-se, além do que se busca

20 Op. Cit. p. 90.

21 Idem. p. 91.

22 Para ZAFFARONI, “(...) não acreditamos que se deve rechaçar de plano os argumentos daqueles que fundam a existência e o arrependimento na 'ponte de ouro' e no 'fim da pena', mas esses podem e devem ser considerados como suportes auxiliares que servem de fundamento à desistência como causa de impunidade" (Op. Cit. p. 93).

23 Apesar da crítica à teoria de LISZT, também adverte FIGUEIREDO DIAS que a "teoria em exame dar a entender muito exactamente que o privilégio é político-criminalmente fundado em vista de aumentar as hipóteses de preservação do bem jurídico e de integridade da esfera da vítima”, o que é adequado (Op. Cit. p. 728). 
seguramente "a dissociação entre o agente e a consumação do seu projecto criminoso" ${ }^{24}$ com a finalidade de proteção do bem jurídico, de inversão de perigo para a vítima, de recompensa pelo mérito de "regresso ao direito", de "reversibilidade da lesão" e de "inversão de perigo".

O segundo aspecto a ser analisado refere-se ao facto de o Código Penal dispor que o agente será beneficiado, se voluntariamente "desistir de prosseguir na execução do crime ou impedir a consumação (...)".

Quanto a esta questão, apontamos que no Código Penal brasileiro há expressa referência aos institutos da "desistência voluntária" e do "arrependimento eficaz", ao contrário do que se verifica em Portugal, que se utiliza tão somente do gênero "desistência" para abranger as duas espécies, apesar da mesma base conceitual.

De qualquer maneira, a primeira parte ("desistir de prosseguir na execução do crime") relaciona-se à denominada "tentativa inacabada", "tentativa abandonada" ou "tentativa imperfeita"); a segunda parte ("impedir a consumação"), à "tentativa acabada", "tentativa perfeita" ou "crime falho".

Na hipótese inicial, o agente ainda não esgotou todos os atos executórios e vem a voluntariamente interromper (abandonar) a conduta delituosa; na outra, todos atos executórios foram praticados, razão pela qual o insucesso - agora desejado - do projeto criminoso não mais depende da cessação da conduta, mas sim de um novo comportamento apto a evitar que o resultado típico venha a ser atingido ${ }^{25}$.

Apesar de não ser uniforme na doutrina, propugnamos que o melhor critério para definir a linha divisória entre a "tentativa inacabada" e a "tentativa acabada" é essencialmente subjetivo, ou seja, é necessário que seja constatado de início o plano do facto pelo autor e, preponderantemente, as circunstâncias concretas de sua execução, no último caso para apurar a representação do autor quanto à prescindibilidade ou não de reiteração de actos com o fim de consumar o delito, o que servirá para responder se, na referida representação, a tentativa estava ou não acabada e, por conseguinte, se a hipótese é de

24 (Idem. p. 730).

25 Na tentativa acabada, é necessária uma ação no sentido contrário à consumação, ou seja, a "movimentação de uma nova cadeia causal", na palavra de FIGUEIREDO DIAS (Op. Cit. p. 740) e que, por intermédio de uma idônea conduta, tenha impedido a consumação do delito. 
abandono da execução ou de necessária contra-conduta com o fim de evitar a consumação do delito 262728 .

Até esta fase do estudo, poderia ser compreendida a eventual inexistência de relevante distinção das regras previstas na lei penal portuguesa e as encontradas em ordenamentos jurídicos de semelhante inspiração.

Porém, na continuidade deste trabalho é possível observar uma ampliação inusual da impunidade pela desistência, ao assim dispor o Código Penal: "a tentativa deixa de ser punível quando o agente voluntariamente (...) impedir a consumação, ou, não obstante a consumação, impedir a verificação do resultado não compreendido no tipo de crime" (art. $\left.24 .^{\circ}, \mathrm{n} \cdot{ }^{\mathrm{o}} 1\right)$.

É cediço que "tentativa" e "desistência" devem ser consideradas em conjunto para correta análise normativa e doutrinária. Mais ainda, "tentativa" e "consumação" são conceitos que, regra geral, não podem coexistir na mesma ação típica, pois a ocorrência da segunda implica ter ultrapassado a primeira.

Por aparente lógica, da mesma forma não seria possível falar em "desistência" se o crime é "consumado".

Entretanto, consoante CAVALEIRO DE FERREIRA, a hipótese em comento nada mais é do que a aceitação da "desistência em um crime consumado"29.

Para melhor elucidação, relembramos que, em determinados crimes, nomeadamente nos denominados "crimes de consumação antecipada", o resultado descrito no tipo penal é prescindível para que o delito caracterize-se como consumado, ou seja, a consumação não coincide com o momento de produção do resultado.

26 De acordo com o mesmo autor “(...) é hoje praticamente unânime que se torna indispensável recorrer às representações do agente sobre o estádio alcançado de realização do facto, só elas podendo servir para determinar se aquele fez já tudo o que intentava fazer para a realização integral do facto e toma por isso a sua verificação, sem mais, por possível" (Op. Cit. p. 734).

27 Na lição de LUIZ FLÁVIO GOMES, a diferença entre tentativa perfeita e imperfeita dependerá: a) do plano do autor; b) do meio escolhido; c) dos atos externos realizados; d) das circunstâncias de cada caso. (Direito Penal. p. 485).

28 Conforme a teoria da consideração conjunta, de maior aceitação, a representação relevante aqui relaciona-se ao último ato de execução, momento em que, para o agente, a conduta já praticada está apta à consumação. Para a teoria do ato individualizado, o relevante é o início da execução em consonância com o seu plano inicial. O exemplo é de FIGUEIREDO DIAS (Op. Cit.: p. 735): "A" intenta matar "B" e, por seu plano inicial, bastaria um tiro para fazê-lo. Efetuado o disparo, a vítima sequer é atingida. Para a teoria, trata-se de tentativa acabada e não mais possível é a desistência, apesar de o revólver ainda estar carregado de projeteis, voluntariamente não utilizados por "A". Constata-se, sem maior dificuldade, que há uma incongruência entre a solução ofertada e o fundamento político-criminal da impunidade pela desistência.

29 Apud PEREIRA, Victor de Sá; LAFAYETTE, Alexandre - Código Penal Anotado e Comentado. p 137. 
Em tais hipóteses, se o resultado que está além do necessário para a consumação do crime for alcançado, afirma-se que houve o "exaurimento" do crime, ou a sua "terminação" ou "conclusão" ou, ainda, a sua "consumação material", que não integram o iter criminis.

Assim, nos crimes de consumação antecipada haverá dois momentos absolutamente distintos: no primeiro, a "consumação formal"; no segundo a "consumação material.

Conforme opção legislativa agora analisada, o regime de privilégio pela desistência pode ser reconhecido ainda que consumado formalmente o delito e desde que não produzido o resultado que inspirou o projeto criminoso, isto é, desde que não verificada a "consumação material", o que é elogiável por permitir maior proteção ao interesse da vítima e alargar a possibilidade de abrangência do privilégio em circunstância compatível com os fundamentos político-criminais da desistência.

Por óbvio, se ultrapassada a consumação formal, a única hipótese de impunidade é mediante uma ação, isto é, uma contra-conduta que impeça a ocorrência do resultado previsto no tipo penal, tal como ocorre na desistência da tentativa acabada (arrependimento ativo e eficaz).

Tal impedimento, ainda, deve ser, como regra, imputável ao agente, ou seja, é necessário que a ele seja atribuída a contra-conduta que se mostrava idónea para impedir a consumação ou evitar a produção do resultado, ainda que, ao final, auxiliado por outra pessoa (teoria da criação de oportunidades) $)^{30}$.

Salientamos ainda a exigência legal de voluntariedade no abandono da execução, o que indica não ser necessário que seja espontâneo e muito menos que o móvel da desistência seja nobre ou que imprescinda de alguma valoração ética.

Embora presentes algumas questões polêmicas a respeito, é preciso destacar que o recuo do agente na prática delituosa quando ainda pode consumar o delito é a característica basilar do conceito. De acordo com FRANK, haverá desistência quando o agente encontra-se na situação "posso, mas não quero consumar o delito" e haverá tentativa se quer praticá-lo, mas não mais puder ${ }^{31}$.

Ainda mais, no sistema de punibilidade decorrente da desistência, não é raro que o delito a ser cometido englobe simultaneamente outro delito. No Código Penal brasileiro, aliás, há

30 Pela teoria da criação óptima, hoje minoritária, deve a conduta do agente espelhar a melhor das opções que teria para evitar a consumação ou que tenha utilizado de todas as opções disponíveis. Para ROXIN (Op. Cit. p. 675), entretanto, há de se distinguir se a consumação foi evitada por ato próprio do agente (impedimento por mão própria) ou por ato preponderante de terceiro (impedimento por mão alheia). No primeiro caso, aplica-se a teoria da criação de oportunidades; no segundo, a teoria da criação óptima. Tal teoria da diferenciação é objeto de crítica por parte de FIGUEIREDO DIAS: "vamos ao ponto de considerar que o privilégio da desistência deve ser concedido ao agente mesmo quando ele se constitui em mero auxiliar do salvamento"(Op. Cit. p. 742).

31 Apud SANTOS, Juarez Cirino - Op. Cit. p. 396. 
expressa menção à punição residual em decorrência da tentativa qualificada, nomeadamente ao dispor que o agente, impune pela tentativa, "responde pelos atos já praticados".

Nesta hipótese, designada "tentativa qualificada", ou seja, quando já consumado um delito que era abrangido pelo outro que foi objeto da desistência, apesar de esta consequência não constar expressamente do Código Penal, não existe discrepância doutrinária e jurisprudencial a respeito de a punição residual ser consequência óbvia”32.

Há outra questão merecedora de destaque: até agora tratamos do impedimento da consumação por obra do agente, hipótese que, embora mais comum, não abarca todas as possibilidades, uma vez que pode ocorrer de a consumação ser impedida por facto independente da contra-conduta do desistente.

Neste caso, de acordo com o art. $24 .^{\circ}$, n. 2, do Código Penal, "Se o sucesso do impedimento da consumação decorre de facto independente de sua conduta, ainda assim será impunivel se tiver esforçado seriamente para evitar a consumação".

A nota fundamental elencada pelo legislador encontra-se na definição do que vem a ser "esforço sério", por nós compreendido, na lição de FIGUEIREDO DIAS, no sentido de que não basta a intenção, ainda que sincera, de afastar a consumação, e sim a tomada de ações que, no âmbito da representação do agente, eram necessários, dentro de suas possibilidades, para efetivamente impedi-la. ${ }^{33}$

Isto exposto, é sempre salutar relembrar ser incabível a impunidade, no sistema do art. $24 .^{\circ}$, se o resultado vier a ocorrer, ainda que tenha o desistente sinceramente buscado, por si ou com auxílio de terceiro, impedi-lo.

Por último, frisamos que, no âmbito da desistência, há previsão na Parte Especial de benefício pela atividade contrária à lesão ou perigo de lesão ao bem jurídico (por exemplo: arts. $161 .^{\circ}, 162 .^{\circ}, 186 .^{\circ}$, n. $^{\circ} 1,362 .^{\circ}$, n. $1 .^{\circ}$, dentre outros), a prevalecer sobre a regulamentação geral inserta nos arts. $24 .^{\circ}$ e $25 .{ }^{\circ}{ }^{34}$.

32 O Código Penal espanhol, em seu art. ${ }^{\circ} 16$, n. $^{\circ}$ 2, também menciona a responsabilidade residual em sua última parte: "(...) sin perjuicio de la responsabilidad en que pudiera haber incurrido por los actos ejecutados, si éstos fueren ya constitutivos de otro delito".

33 Neste aspecto, o esforço sério deve ser "demostrado através de actos concretos (não basta a mera intenção) mas, que, todavia, não foi determinante para o evitar (arrependimento activo, mas ineficaz)" (SANTOS, Simas; HENRIQUES, Leal - Noções de Direito Penal. p. 137).

34 GARCIA, M. Miguel; RIO, J. M. Castela - Código Penal: Parte Geral e Especial. p. 197. 


\section{Comparticipação}

Se, em regra, o crime é obra de uma só pessoa, não é raro que para sua realização - e não necessariamente execução - mais de uma colabore, o que vem a ser denominado "comparticipação"35.

As consequências jurídicas advindas do facto de se tratar de autor singular ou de comparticipação são percebidas em várias ocasiões, a incluir a desistência, nomeadamente por ter o legislador diversificado as soluções potencialmente cabíveis a depender dos papéis desempenhados por cada um dos colaboradores.

Dispõe o art. 26. ${ }^{\circ}$ do Código Penal: "É punível como autor quem executar o facto, por si mesmo ou por intermédio de outrem, ou tomar parte directa na sua execução, por acordo ou juntamente com outro ou outros, e ainda quem, dolosamente, determinar outra pessoa à prática do facto, desde que haja execução ou começo de execução"36.

Assim, de acordo com o Código Penal, é possível que ao indivíduo seja imputado o injusto penal na condição de autor, instigador ou cúmplice ${ }^{37}$.

Além disso, da redação acima transcrita são indicadas, de maneira inequívoca, as seguintes formas de autoria: "autoria imediata" (quem executa o facto por si mesmo), "autoria mediata" (quem executa o facto por intermédio de outro) e "coautoria" (quem tomar parte direta na sua execução, por acordo ou juntamente com outro ou outros).

Para estabelecer o ponto comum entre as espécies de autoria, necessário fixar que, pela teoria do domínio do facto, de induvidosa aplicação, autor é quem domina o facto, que é, por assim dizer, "senhor" do facto, de forma tal que dele dependerá o se e o como da realização do crime a caracterizar, em síntese, a "figura central dos acontecimentos" 38 .

Exposto isto, observemos que a semelhança entre as referidas espécies é que o autor, por diferentes formas, possui o domínio do facto, a saber: a) na autoria imediata, é o possuidor do domínio da ação; b) na autoria mediata, possui o domínio da vontade; c) na coautoria, é possuidor do domínio funcional do facto ${ }^{39}$.

Ressaltamos que, embora seja possível estabelecer a possibilidade de aplicação da teoria para grande parte dos delitos (neste sentido, denominados "delitos de domínio"), afasta-se

35 No Código Penal brasileiro denomina-se "concurso de pessoas".

36 Para FIGUEIREDO DIAS, as principais características do Código Penal vigente a respeito da comparticipação seriam as seguintes: a) adoção do conceito restritivo de autor nos crimes dolosos; b) instigação como forma de autoria, o que por muitos é rechaçado; c) acolhimento do princípio da comunicabilidade das circunstâncias relativas ao delito (Op. Cit. p. 773).

37 A classificação é polêmica em virtude da inserção do instigador na autoria por parcela da doutrina portuguesa, o que será objeto de maior aprofundamento adiante.

38 Op. Cit. p. 766.

39 Os precursores da teoria do domínio do facto são, nomeadamente, LOBE, WELZEL e GALLAS, vindo a merecer um estudo mais sistemático por parte de ROXIN com a obra "Autoria e Domínio do Facto". 
a incidência nos delitos negligentes, delitos omissivos, "delitos de dever" e "crimes de mão própria".

Ponto central da teoria do domínio do facto é a denominada "autoria mediata", a qual, como visto, significa o domínio da vontade: o autor mediato (homem-de-trás) utiliza-se de terceiro (homem-da-frene) como instrumento para a prática do delito, em especial quando este (a) age sem dolo, (b) age atipicamente, (c) age justificadamente, (d) é inculpável ou quando (e) age sem consciência do ilícito.

Para ROXIN ${ }^{40}$, acrescenta-se ainda o domínio da vontade nos quadros de aparelhos organizados de poder, o que vem a ${ }^{41}$ ser combatido por FIGUEIREDO DIAS.

Para tal oposição, aduz que o fundamento da autoria mediata é a autorresponsabilidade, razão pela qual não se pode admitir a possibilidade de autoria mediata quando o terceiro (homem-da-frente) é plenamente responsável, pois em tal situação o homem-de-trás efetivamente não possui o domínio do facto. Não é possível, assim, afirmar que a ação ocorreu por intermédio de um instrumento. Por tudo, a hipótese é de efetiva instigação (espécie de autoria, para FIGUEIREDO DIAS) ${ }^{42}$.

Apesar das críticas, é prevalecente a posição de ROXIN, cuja tese é bem acolhida na jurisprudência alemã, no Direito Penal internacional e em Tribunais de outros países ${ }^{43}$.

Quanto à coautoria, importante a advertência de que esta espécie não implica a necessidade de o agente praticar atos expressamente descritos no tipo penal, mas que exista uma repartição de tarefas abrangida pelo plano conjunto e que, de acordo com cada atividade desempenhada, possa ser apurado que a execução do facto é "dependente daquela mesma repartição", de forma tal que nenhum dos coautores "necessita de preencher na própria pessoa a totalidade dos elementos típicos"44.

42 Para WELZEL, "autoria mediata por meio de um executor imediato que é, ele mesmo, autor, é um não conceito (Unbegriff)" (Apud GRECO, Luís - Autoria como Domínio do Facto. p. 210).

43 Afirma LUÍS GRECO a respeito de não ser possível erigir o princípio da autorresponsabilidade como obstáculo intransponível à tese de ROXIN: "Na melhor das hipóteses, ao princípio da autorresponsabilidade pode ser atribuído o significado de caracterizar um grupo de casos no qual a autoria mediata pode ser afirmada: caso o homem da frente atue de forma não responsável, o domínio e, assim, autoria mediata do homem de trás são mais facilmente afirmados. O princípio não pode, no entanto, almejar nem a uma delimitação de todo o espectro da autoria mediata e do domínio da vontade e nem, com mais razão, à determinação da autoria de todos os delitos de domínio, isto é, de todos os delitos nos quais o conceito geral de domínio do facto é de significado fundamental. É menos plausível ainda defendê-lo como um princípio geral, válido para todo Direito (Penal). É por isso que o princípio não oferece uma razão para duvidar da possibilidade de um autor por trás de um autor plenamente responsável e, especialmente, da autoria mediata por meio do domínio da organização" (Op. Cit. p. 214).

44 DIAS, Jorge de Figueiredo - Op. Cit. p. 794. 
Ponto de intensa polêmica refere-se à inserção do instigador, ou seja, aquele que determinar outra pessoa à prática do facto, no gênero "autoria", posição defendida por FIGUEIREDO DIAS, embora com divergência de parte da doutrina penal portuguesa que compreende ser correta a presença dos instigadores, assim como dos cúmplices, em categoria distinta da autoria e, portanto, abrangida pela "participação"45.

Para ele, a opção do legislador foi deliberada ao colocar a instigação ao lado da autoria imediata, da autoria mediata e da coautoria, em artigo (art. $26 .^{\circ}$ ) distinto da cumplicidade (art. 27..$^{\circ}$.

Em sentido contrário ao sustentado, argumenta-se que não é possível concluir, a partir da redação do Código Penal, que a instigação é um forma ou espécie de autoria, mas tão somente que o instigador "é punível como autor (...)" (art. 26. ${ }^{\circ}$ ).

Outro argumento para afastar a inserção da instigação como autoria é o facto de a redação do art. $26 .^{\circ}$ reforçar o acessoriedade da instigação, nomeadamente ao dispor que somente será o instigador punido se houver "execução ou começo de execução".

De qualquer forma, não se discute que o instigador não executa diretamente o crime e tampouco o executa por intermédio de outrem como instrumento, sendo o domínio do facto, agora novamente de acordo com FIGUEIREDO DIAS, decorrente do domínio da decisão ${ }^{46}$.

Apesar disto, adverte o mesmo doutrinador que não é todo ato de instigação que acarreta a "determinação", pois muitos deles, apesar de abrangidos pelo amplo conceito, podem apresentar natureza de aconselhamento, sugestão ou mero reforço ao projeto delituoso já aventado pelo eventual executor, o que afasta a "instigação-determinação" imprescindível à caracterização de autoria e possibilita a sua inserção na cumplicidade moral.

Ainda mais, há controvérsia, por exemplo, quanto à figura do aliciamento, uma vez que há autores inserem a instigação sempre na participação e não na autoria, ou seja, quando o executor (aliciado) age mediante uma contrapartida de uma prestação a ser adimplida pelo aliciador, presente está a "autoria mediata", posição rechaçada por FIGUEIREDO DIAS sob o argumento de que em tais casos o aliciador não possui o domínio da vontade e sim o mero domínio da decisão, o que o faz instigador, solução coerente com as sua concepções sobre o princípio fulcral da autorresponsabilidade e da instigação como autoria ${ }^{47}$.

45 A polêmica não parece existir na doutrina penal espanhola e tampouco na alemã, pois é posição praticamente uniforme que a instigação não está abrangida pela "autoria".

46 Em síntese, "o instigador surge assim (mas só então) como verdadeiro senhor, dono ou dominador se não do ilícito típico como tal, ao menos e seguramente da decisão do instigado de o cometer; determinação esta desta maneira integra, por antecipação, a totalidade dos elementos constitutivos do ilícito típico e, por isso também, do conteúdo material do ilícito. (...). Só esta é, no entendimento da nossa lei, a instigação-determinação e, por conseguinte, a instigação que é autoria" (Op. Cit. p. 800).

47 Op. Cit. p. 807 . 
A respeito da cumplicidade (moral ou material), a prática do facto principal não depende do referido contributo, embora seja por ela beneficiada, o que é resultante da leitura do art. 27. ${ }^{\circ}$, n. ${ }^{\circ}$ 1, do Código Penal: "É punível como cúmplice quem, dolosamente e por qualquer forma, prestar auxílio material ou moral à prática por outrem de um facto doloso".

Por ser induvidosamente participação, apresenta-se acessória da autoria no sentido de que o cúmplice colabora (moral ou materialmente) no "facto do autor", daí a razão de não haver cumplicidade punível se o facto principal não é executado.

Acrescenta-se que, para a cumplicidade ser punível, além do mencionado início da execução, é ncesessário que o facto principal seja típico e ilícito (teoria da acessoriedade limitada), independentemente da culpabilidade e da punibilidade ${ }^{48}$.

Ao contrário do que ocorre na instigação, cuja punição é similar ao previsto para o autor, na cumplicidade a pena, ainda tendo como referência a do autor, merece especial atenuação (art. 27. ${ }^{\circ}$, n. ${ }^{\circ}$ 2, do Código Penal).

\section{Desistência em Caso de Comparticipação}

Ao contrário do que ocorre na legislação penal brasileira, há no Código Penal português expressa e específica regulamentação a respeito da desistência em caso de comparticipação, o que indica ter o legislador corretamente percebido que a regra de desistência para o autor singular não preenche com exatidão as particularidades da ação típica patrocinada por uma pluralidade de pessoas que desempenham diversos papéis na obra criminosa conjunta.

48 São quatro as teorias com pretensão de responder os níveis de acessoriedade da participação em relação à autoria: a) teoria da acessoriedade mínima: para que a participação (natureza acessória) seja punível é necessário que o facto principal seja tão-somente típico. "A" auxilia "B" a praticar ato em situação de legítima defesa. Se a excludente também não for pertinente ao partícipe, será punido pelo ato praticado por "B”; b) teoria da acessoriedade limitada: para que a participação (natureza acessória) seja punível é necessário que o facto principal seja típico e antijurídico. "A" auxilia "B" a praticar ato em situação de legítima defesa. "A" também não será punido, pois o ato praticado por "B" não é antijurídico. Esta corrente é a mais aceita na doutrina e na jurisprudência; c) teoria da acessoriedade máxima: para que a participação (natureza acessória) seja punível é necessário que o facto principal seja típico, antijurídico e culpável. "A" instiga "B", menor com 17 anos, a subtrair um automóvel. Por ser "B" inculpável pela inimputabilidade, "A" também não seria punido pelo furto como partícipe. Os que defendem tal teoria alegam que "A" poderia ser punido como autor mediato por ser "B" inculpável; d) teoria da hiperacessoriedade: aduz que a punição do partícipe depende de o autor ter praticado uma conduta típica, antijurídica, culpável e punível. "A" instiga "B" a subtrair um relógio do pai. "B", em razão de escusa absolutória não é punido pela subtração. "A" também não seria punido. Esta corrente diverge de forma absoluta do Código Penal, o qual textualmente determina que o terceiro que participa do crime é punido pela subtração praticada por descendente contra ascendente. 
Em comum, podemos dizer que a regra da desistência na comparticipação é marcada por seu caráter subjetivo quanto à impunidade, pois somente beneficia aquele que desiste ou impede a produção do resultado ${ }^{49}{ }^{5}$.

Historicamente, a Reforma do Código Penal de 1884 inseriu a primeira referência à desistência do comparticipante e que veio a ser mantida no Código Penal de 1886 (art. 20. ${ }^{\circ}$, $\S$ único): "A revogação do mandato deve ser considerada como circunstância atenuante especial, não havendo começo de execução do crime, e, como simples circunstância atenuante, quando já tiver havido começo de execução".

$\mathrm{Na}$ redação vigente, especificamente no art. $25{ }^{\circ}$ do Código Penal, "se vários agentes comparticiparem no facto, não é punível a tentativa daquele que voluntariamente impedir a consumação ou a verificação do resultado, nem a daquele que se esforçar seriamente por impedir uma ou outra, ainda que os outros comparticipantes prossigam na execução do crime ou o consumem".

Em síntese, as possibilidades do privilégio pela desistência relacionam-se às seguintes hipóteses, alternativamente: a) impedimento da consumação mediante uma contra-conduta; b) impedimento da produção do resultado não compreendido no tipo mediante uma contra-conduta, se já consumado formalmente o delito; c) esforço sério para impedir a consumação ou a produção do resultado, ainda que não seja bem sucedido no novo propósito em virtude da continuidade da execução pelos outros comparticipantes e mesmo que o crime se consume.

É facilmente constatável que, apesar da base comum com o art. $24 .^{\circ}$ do Código Penal, há maior amplitude no reconhecimento das hipóteses de não punição e, no limite - e de maneira não comum - é possível a aplicação da regra benéfica ainda que consumado o crime, situação não prevista no regime do artigo anterior ${ }^{51}$.

O fundamento político-criminal para a ampliação do benefício vincula-se à expectativa de maior proteção do bem jurídico pela contra-conduta do comparticipante que, assim, poderá levar até o ultimo momento o novo propósito de impedir a verificação do resultado,

49 Há dissenso em relação à desistência do autor, pois, por se tratar de causa pessoal que afasta a punição, o cúmplice não seria por ela beneficiado. Entretanto, alguns doutrinadores, ainda que se filiem ao entendimento antes referido, compreendem que, independente da normatização específica do instituto ("desistência"), a participação, posto ser acessória, segue o mesmo destino reservado à autoria.

50 De acordo com FIGUEIREDO DIAS, “(...) desistência voluntária significa desistência como obra do agente, a ele imputável, o privilégio liga-se estritamente à conduta pessoal do desistente e não se estende aos outros comparticipantes" (Op. Cit. p. 742).

51 “Trata-se, pois, de diferentes graus de exigência no tratamento da desistência do 'autor singular', por contraposição àquela que ocorre por parte de um (ou mais) comparticipantes" (PINTO, Frederico de Lacerda da Costa - A relevância da desistência em situações de comparticipação. p. 33). 
daí por que reconhecer o mérito de sua contra-conduta, mesmo que infrutífera e desde que se tenha esforçado seriamente para impedi-lo ${ }^{52}$.

A intenção do legislador, verifica-se, é mostrar ao comparticipante a utilidade da "dessolidarização" a ser materializada na contra-conduta.

É claro que tal modelo, até mesmo pela singularidade, não é similar ao encontrado em outros relacionados à desistência na comparticipação, a saber: a) modelo restritivo: o privilégio somente será reconhecido se a consumação for evitada, o que, no limite, pode implicar responsabilização do desistente por facto alheio, com excessiva preponderância do aspecto objetivo; b) modelo causalista, a contra-conduta do comparticipante deve ter força para "neutralizar" a "eficácia causal" da colaboração anterior já prestada,; c) modelo amplo: somente bastará o abandono da colaboração pelo comparticipante desistente, com nítida preponderância do aspecto subjetivo e mitigada proteção do bem jurídico ${ }^{53}$.

Logo, a opção do legislador português, embora, assim como em outros modelos, não seja imune a críticas, tem o mérito de maior proteção do bem jurídico e de consideração ao "regresso ao direito" do comparticipante desistente, ainda que infrutífera a sua contra-aconduta, mas desde que resultante de um esforço sério para impedir a consumação.

De toda forma, é óbvio que a norma penal em comento não soluciona todas as questões pertinentes à matéria e, para dirimi-las, a primeira a ser analisada refere-se aos destinatários do regime mais benevolente previsto no art. $25 .^{\circ}$ do Código Penal.

Para FIGUEIREDO DIAS, a totalidade dos comparticipantes é abrangida pela específica regulamentação (autores mediatos, coautores, instigadores e cúmplices), com exceção tão somente "aos casos de autoria mediata, ainda que neles intervenha um cúmplice estranho à desistência"54.

Com idêntica solução, ROXIN afirma que, no caso de autoria imediata na qual houve a colaboração de um cúmplice, não há o porquê de estar abrangida a desistência do autor pela específica regulamentação do art. $25^{\circ}$, se o abandono não tem pertinência com aquele que o auxiliou ${ }^{55}$.

Há, portanto, relativa concordância sobre a não aplicação do art. $25 .^{\circ}$ em todos os casos de comparticipação, o que impõe a necessidade de estabelecer um critério que ultrapasse o aspecto meramente formal.

52 DIAS, Jorge de Figueiredo - Op. Cit. p. 845.

53 A rejeição a esse modelo é observada no Ac. STJ de 14/12/1995, quando os julgadores decidiram que, na hipótese de comparticipação (no caso, coautoria), o privilégio da desistência somente pode ser conferido se advier o "arrependimento ativo" pelo desistente, isto é, não basta o abandono e a cientificação ao outro comparticipante e sim o "agir" para evitar a consumação.

54 Op. Cit. p. 844.

55 Apud DIAS, Jorge de Figueiredo - Op. Cit. p. 843 
Porém, é exactamente nesta definição material que são encontradas as primeiras divergências.

A primeira delas refere-se à autoria mediata, pois, para FIGUEIREDO DIAS, tal espécie de autoria estaria abrangida pelo art. $25^{\circ}{ }^{\circ}$, independente de ser ou não o homem-da-frente impunível: "também os comparticipantes não puníveis são comparticipantes para efeitos do art. $25 \cdot{ }^{0 "}{ }_{56}$.

Tal posição confronta sobremaneira com o pensamento de COSTA PINTO, autor da monografia mais aprofundada da relevância da desistência em caso de comparticipação.

Para o mencionado autor, a maior benevolência do art. $25 .^{\circ}$ em relação ao art. $24 .^{\circ}$, nomeadamente quanto à possibilidade do regime de privilégio ainda que o crime venha ser consumado pelos outros comparticipantes, decorre do que denominou "risco de insucesso da desistência": na comparticipação, não é correto que o desistente suporte todo o risco de o crime consumar-se, sob pena de responsabilizar-se por facto de outrem, ou seja, dos comparticipantes não desistentes e que foram responsáveis pela consumação do delito - apesar da contra-atividade de um dos agentes.

Por coerência argumentativa, aduz que o art. $25 .^{\circ}$ aplica-se aos comparticipantes não possuidores do "domínio positivo" sobre a consumação do delito, não merecedores, portanto, de suportar todo o risco de insucesso da desistência, enquanto os agentes que possuírem tal domínio, exclusivo ou repartido, ainda que não executores diretos da ação típica, serão abrangidos pela norma menos benéfica do art. $24 .^{\circ}$ do Código Penal ${ }^{57}$.

A comparticipação, assim, apenas autoriza prima facie a inserção no art. $^{\circ} 25$, cujo efetiva abrangência dependerá de outros critérios que ao primeiro requisito devem aderir.

Neste contexto, cúmplices e instigadores, por não exercerem ou não terem exercido o domínio positivo da consumação, estariam abrangidos pelo art. $25^{\circ}$, enquanto ao executor (autores imediatos, ainda que em situação de comparticipação) restaria a abrangência do art. $24 .^{\circ}$ do Código Penal.

$\mathrm{Na}$ autoria mediata, como antes visto, o facto delituoso é praticado por intermédio de outrem (instrumento), o que equivale a afirmar que o domínio positivo (e até negativo) da ação é subtraído do executor e conferido ao autor mediato.

Neste caso, por lógica, o autor mediato está abrangido pelo art. $24 .^{\circ}$ do Código Penal, salvo se o "instrumento" possuir alguma vontade autónoma, posição aceita por aqueles que admitem a "relativização" do princípio da autorresponsabilidade.

56 Op. Cit. p. 844

57 Sob tal raciocínio, por não possuir o agente abrangido pelo art. $25 .^{\circ}$ o domínio positivo da consumação, é que nele não há referência ao abandono da tentativa, cuja pertinência somente é conferida aos que a dominem. 
Em relação à coautoria, a priori estaria inserida no art. $^{0} 24$ por serem os coautores possuidores do domínio repartido sobre a consumação do delito e, sem a aceitação de sua atividade, como regra não seria bem sucedido o propósito criminoso, "o que permite que o mesmo lhe seja integralmente imputado, apesar da sua execução por esse interveniente ser apenas parcial" ${ }^{58}$.

O mesmo doutrinador, entretanto, em arguta explanação sobre o tema, aponta que há duas hipóteses nas quais a relevância da desistência na coautoria pode ser cindida, tudo a depender do papel desempenhado pelos protagonistas.

Assim, na "coautoria dependente" verifica-se que um dos agentes não possui o domínio negativo da consumação em relação ao outro comparticipante e tampouco o domínio positivo da consumação: no exemplo por ele elaborado, "C" imobiliza a vítima enquanto "A" a estrangula. No caso de "C" desistir da execução, o domínio positivo da consumação continuará com "A". Portanto, "C" é abrangido pelo regime do art. 25. ${ }^{\circ}$ e "A" pelo art. $24 .^{\circ}$, uma vez que somente ele possuía o domínio positivo da consumação.

No caso, "A" era possuidor apenas do domínio positivo de sua própria atividade e do domínio negativo da consumação, porém sem possibilidade fática de estender tal domínio aos atos do outro comparticipante. Logo, não seria correto, no caso, que 'A" suportasse todo o risco do insucesso da desistência.

Outra resposta mereceria ser dada se "A" também tivesse o domínio negativo sobre os atos de execução do outro comparticipante, o que COSTA PINTO designou de "coautoria complementar": neste caso, a consumação somente ocorrerá com a soma das atividades desempenhadas para cada comparticipante, embora quando isoladas não sejam aptas, por si, a consumar o delito.

Exemplo: "A" e "C" decidem matar a vítima estrangulada do seguinte modo: a corda é passada ao redor do pescoço da vítima e cada um dos comparticipantes a puxa ao mesmo tempo e em direção oposta. Logo, se somente um deles puxar e o outro ficar inerte (desistente), a consumação não ocorrerá. Se ambos puxarem, a vítima morrerá estrangulada. Ambos, portanto, não possuem exclusivamente o domínio positivo sobre a consumação, porém a possuem de maneira repartida e de forma que o sucesso do propósito criminoso imprescinde da contribuição de cada um, o que implica exercício repartido do domínio positivo do facto e negativo sobre a execução relacionada ao outro.

Assim, também na mesma linha antes exposta, ambos serão abrangidos pelo privilégio da desistência previsto no art. $24 .^{\circ}$, embora seja induvidosamente uma hipótese de comparticipação. 
Apesar da objeção de FIGUEIREDO DIAS a estas soluções propostas por COSTA PINTO, é difícil sustentar a posição de que todos os comparticipantes estariam abrangidos pelo art. $25 .^{\circ}$, cujos requisitos de concessão são mais amplos, uma vez que restaria incongruente o possuidor do domínio positivo da consumação na autoria singular incidir no art. $24 .^{\circ}$, mais restritivo, enquanto o outro, que também possui o mesmo domínio e ainda conta com o contributo de outro agente, ficar em situação mais favorável ${ }^{59}$.

Acrescentamos que a impunidade, no último caso, dependerá de o agente se esforçar seriamente para impedir a consumação ou a verificação do resultado, ainda "que os outros comparticipantes prossigam na execução do crime ou o consumem".

Para reconhecimento do "esforço serio" não bastam a "revogação do mandato", a "tentativa de convencimento" dos demais e a eventual "neutralização da colaboração prestada", se o desistente possui ciência da pouca relevância dos referidos caminhos em relação aos comparticipantes ${ }^{60}$.

Exige-se, sobremaneira, que a conduta seja idônea ou adequada à defesa do bem jurídico em perigo, de acordo com um juízo de prognose póstuma, além do que, a depender das circunstâncias em concreto, não se conforme o desistente com o fracasso da medida inicialmente considerada idônea, a exigir, portanto, a busca de medidas alternativas "enquanto subsistir a situação de perigo para os bens jurídicos"61.

Finalmente, compreendemos que, caso os demais venham a alterar o curso da execução em virtude da desistência, será ao desistente reconhecido o privilégio, uma vez que a execução de "outro facto" pelos comparticipantes não pode a ele ser imputada.

\section{Conclusões}

Constatamos no presente relatório que a legislação portuguesa relacionada à desistência em caso de comparticipação é digna de elogios e compatível com um Direito Penal cuja função é preponderantemente a proteção de bens jurídicos.

Neste sentido e a título comprativo, observamos que a legislação penal brasileira, ao contrário, não regulamenta a matéria e acaba por possibilitar equivocadas soluções doutrinárias sobre questões mais delicadas, como é o caso da posição que sustenta a atipicidade

59 Idem. p. 272

60 De acordo com Ac. STJ de 18/04/2012 (274/10.9JACBR.CI.SI), o benefício pela desistência imprescinde de o agente dominar isoladamente ou ao menos em conjunto (condominação) o processo de salvamento do bem jurídico. (GARCIA, M. Miguel; RIO, J. M. Castela - Op. Cit. p. 177).

61 DIAS, Jorge de Figueiredo - Op. Cit. p. 847. 
da tentativa em caso de desistência, desprezando-se a repercussão se praticado o delito por uma pluralidade de agentes em comparticipação.

A ampliação da relevância da desistência até mesmo se consumado formalmente o crime e antes da produção do resultado é outra previsão bastante adequada, tanto no que se refere ao interesse do ofendido quanto ao reconhecimento do mérito do desistente no "regresso ao direito".

Nomeadamente no regime de privilégio estabelecido pelas regras da desistência em caso de comparticipação, é também objeto de acerto a concessão do regime privilegiado ao comparticipante que se esforçou seriamente para impedir a consumação, ainda que esta venha a ocorrer, solução única quando comparada a outros ordenamentos jurídicos.

A respeito da abrangência do art. $25 .^{\circ}$ do Código Penal, aderimos à posição de COSTA PINTO sobre a necessidade de análise aprofundada dos papeis desempenhados por cada agente, a não bastar a mera existência de comparticipação para excluir o regime mais restritivo do art. $24 .^{\circ}$ do mesmo estatuto legal.

Neste contexto, somos pela inserção dos autores imediatos, ainda que auxiliados pelo cúmplice, dos autores mediatos, quando o executor não é plenamente responsável, e dos coautores, a incluir a hipótese de coautoria complementar, no art. $24 .^{\circ}$ do Código Penal.

Ao contrário, instigadores (em relação aos quais não consideramos abrangidos pela "autoria"), cúmplices e coautor dependente que não possua domínio positivo da consumação seriam insertos no regime do art. $25 .^{\circ}$, mais benevolente.

Por último, apontamos que a desistência é causa pessoal que afasta a punição (salvo na hipótese de "tentativa qualificada"), o que impede que tal circunstância seja comunicável com o comparticipante que não está abrangido pelo regime de privilégio estabelecido pelas regras a ela pertinentes.

\section{BIBLIOGRAFIA}

BITENCOURT, Cezar Roberto; CONDE, Francisco Muñoz - Teoria Geral do Delito. São Paulo: Saraiva, 2004. COSTA, José Francisco de Faria - Formas de Crime. Lisboa: Ed. CEJ, sd.

DIAS, Jorge de Figueiredo - Direito Penal: Parte Geral. Coimbra: Coimbra Editora, 2012.

FRAGOSO, Heleno Cláudio; HUNGRIA, Nelson - Comentários ao Código Penal. Rio de Janeiro: Forense, 1978.

GARCIA, M. Miguel; RIO, J. M. Castela - Código Penal: Parte Geral e Especial. Coimbra: Livraria Almedina, 2014.

GOMES, Luiz Flávio - Direito Penal: Parte Geral: v. 2. São Paulo: Revista dos Tribunais, 2007.

GRECO, Luís - Domínio da organização e o chamado princípio da autorresponsabilidade. In Autoria como Domínio do Facto: Estudos introdutórios sobre o concurso de pessoas no Direito Penal brasileiro. São Paulo: Marcial Pons, 2014, p. 203-214. 
Desistência em Caso de Comparticipação

PEREIRA, Victor de Sá; LAFAYETTE, Alexandre - Código Penal Anotado e Comentado. Lisboa: Quid Juris, 2014.

PINTO, Frederico de Lacerda da Costa - A relevância da desistência em situações de comparticipação. Coimbra: Livraria Almedina, 1992.

PRADO, Luiz Regis - Curso de Direito Penal Brasileiro: Parte Geral. São Paulo: Revista dos Tribunais, 2002. ROXIN, Claus - Derecho Penal: Parte General - Tomo 2. Madrid: Civitas-Thomson Reuters, 2014.

SANTOS, Juarez Cirino - Direito Penal: Parte Geral. Curitiba: ICPC; Lumen Juris, 2006.

SANTOS, Simas; HENRIQUES, Leal - Noções de Direito Penal. Lisboa: Reis Livros, 2016.

SIQUEIRA, Galdino - Tratado de Direito Penal. Rio de Janeiro: José Konfino, 1947.

ZAFFARONI, Eugênio Raúl - Da Tentativa: Doutrina e Jurisprudência. São Paulo: Revista dos Tribunais, 2008. 